\title{
Penerapan Model Pembelajaran Group Investigation dengan Multimedia untuk Meningkatkan Kerja Sama Siswa dalam Mata Pelajaran IPS Kelas IV SD Negeri 1 Wonosari Tahun Ajaran 2017/2018
}

\author{
Rahmahwati ${ }^{1}$, Tri Saptuti Susiani ${ }^{2}$, Moh. Salimi ${ }^{3}$ \\ 1,2,3 Universitas Sebelas Maret \\ rahmahwati064@gmail.com
}

\section{Article History}

accepted 01/02/2019

approved 01/03/2019

published 01/04/2019

\begin{abstract}
The objective of this research is to improve students' teamwork in social science learning through the implementation of Group Investigation learning model using multimedia. This research is a collaborative Classroom Action Research (CAR) conducted within three cycles. Subjects of the research were teacher and the fourth grade students. Techniques of collecting data were observation, interview, questionnaire, and test. Validity of data in this research was analyzed using triangulation of sources and triangulation of technique. Data analysis consists of data reduction, data display, and drawing conclusion. The results of this research show that the implementation of Group Investigation learning model using multimedia can improve the fourth grade students' teamwork in social science learning.
\end{abstract}

Keywords: Group Investigation, multimedia, teamwork

\section{Abstrak}

Tujuan penelitian ini yaitu untuk meningkatkan kerja sama siswa dalam mata pelajaran IPS melalui penerapan model pembelajaran Group Investigation dengan multimedia. Penelitian ini merupakan penelitian tindakan kelas (PTK) kolaboratif yang dilaksanakan dalam tiga siklus. Subjek penelitian ini adalah guru dan siswa kelas IV. Teknik pengumpulan data menggunakan observasi, wawancara, angket, dan tes. Validitas data menggunakan triangulasi teknik dan sumber. Analisis data meliputi reduksi data, penyajian data, dan kesimpulan. Hasil penelitian ini menunjukkan bahwa penerapan model pembelajaran Group Investigation dengan multimedia dapat meningkatkan kerja sama siswa dalam mata pelajaran IPS kelas IV.

Kata Kunci: Group Investigation, multimedia, kerja sama 


\section{PENDAHULUAN}

IImu Pengetahuan Sosial (IPS) merupakan salah satu mata pelajaran yang penting untuk dipelajari siswa sekolah dasar. Melalui pembelajaran IPS, siswa sekolah dasar diharapkan mampu dikembangkan aspek pengetahuan, aspek nilai-sikap, dan aspek keterampilan sosial (Susanto, 2014: 36). Dalam Permendiknas Nomor 22 Tahun 2006 diuraikan bahwa tujuan pembelajaran IPS adalah agar peserta didik memiliki kemampuan: (1) mengenal konsep-konsep yang berkaitan dengan kehidupan masyarakat dan lingkungannya; (2) memiliki kemampuan dasar untuk berpikir logis dan kritis, rasa ingin tahu, inkuiri, memecahkan masalah, dan keterampilan dalam kehidupan sosial; (3) memiliki komitmen dan kesadaran terhadap nilai-nilai sosial dan kemanusiaan; (4) memiliki kemampuan berkomunikasi, bekerja sama dan berkompetisi dalam masyarakat yang majemuk, di tingkat lokal, nasional, dan global.

Berdasarkan tujuan pembelajaran IPS, salah satu keterampilan sosial menjadi kompetensi yang perlu dimiliki peserta didik adalah kerja sama. Pentingnya memiliki keterampilan kerja sama sesuai pendapat Johnson, Johnson \& Holubec bahwa selain keterampilan akademis, keterampilan kerjasama juga harus diberikan kepada peserta didik, karena keterampilan kerjasama bermanfaat bagi mereka untuk meningkatkan kerja kelompok dan menentukan keberhasilan hubungan sosial di masyarakat (Apriono, 2013: 296).

Menurut Johnson \& Johnson, "Kerja sama yaitu mengerjakan sesuatu bersama-sama dengan saling membantu satu sama lainnya sebagai satu tim untuk mencapai tujuan bersama" (Isjoni, 2013: 45). Huda (2015: 31) berpendapat bahwa kerja sama siswa dalam pembelajaran merupakan pembentukan kelompok-kelompok kecil yang terdiri dari siswa-siswa yang dituntut untuk saling bekerja sama dan saling meningkatkan pembelajarannya serta pembelajaran siswa-siswa lain.

Namun berdasarkan hasil observasi pada pembelajaran IPS kelas IV di SDN Wonosari Kecamatan Kebumen Kabupaten Kebumen pada tanggal 1 November 2017 menunjukkan bahwa kerja sama siswa masih rendah. Hal ini dapat diamati ketika pembelajaran berlangsung yaitu: (1) siswa cenderung pasif; (2) pembagian tugas yang tidak merata; (3) kurang menghargai pendapat; dan (4) partisipasi siswa yang rendah. Proses pembelajaran yang kurang efektif tersebut ternyata berpengaruh pada hasil belajar siswa. Dalam pembelajaran IPS, guru sudah menerapkan variasi model diskusi berkelompok, namun dalam pelaksanaannya kurang efektif dan masih terpusat pada siswa (student centered). Siswa seharusnya aktif bekerja sama dalam kelompok. Menurut Perspektif Piagentian ketika siswa aktif bekerja sama, konflik sosio-kognitif atau perdebatan pemikiran akan muncul yang nantinya akan meningkatkan pemahaman siswa (Huda, 2015: 39-40).

Dalam menumbuhkan kerja sama siswa dibutuhkan model pembelajaran yang tepat. Model pembelajara Group Investigation merupakan tipe pembelajaran kelompok yang memberikan kontrol dan pilihan penuh pada siswa untuk merencanakan apa yang ingin dipelajarai dan diinvestigasi. Setiap anggota kelompok turut andil dalam berdiskusi dan menentukan informasi apa yang ingin dikumpulkan, bagaimana mengolahnya, bagaimana menelitinya, dan bagaimana menyajikan penelitiannya didepan kelas (Huda, 2015: 123-124). Dengan adanya keterlibatan siswa, diharapkan kerja sama siswa dapat meningkat. Hal ini dibuktikan dengan penelitian yang dilakukan oleh Jajang Nurjaman (2014) dan Wahyuningtiyas (2014) yang menyatakan bahwa penerapan metode Group Investigation dapat meningkatkan kerja sama siswa dilihat perilaku siswa berdasarkan tingkat pencapaian indikator kerja sama yaitu kontribusi setiap anggota kelompok, tanggung jawab kelompok dalam menyelesaikan tugas, penyamaan seluruh pendapat seluruh anggota, dan sikap saling membantu antar anggota kelompok.

Pelaksanaan model Group Investigation membutuhkan berbagai sumber informasi dalam penyelidikan sehingga dibutuhkan media yang beragam sebagai 
sumber informasi. Multimedia terdiri dari beberapa media yang konvergen, misalnya media visual dan audio yang dapat berupa media powerpoint disertai gambar dan video untuk menampilkan isi pelajaran (Arsyad, 2014: 162). Dengan menggunakan multimedia interaksi siswa dengan guru dapat meningkat dan memotivasi siswa untuk terlibat aktif dalam pembelajaran.

Berdasarkan uraian diatas, peneliti melaksanakan penerapan model pembelajaran Group Investigation dengan multimedia untuk meningkatkan kerja sama siswa dalam pembelajaran IPS kelas IV SDN 1 Wonosari tahun ajaran 2017/2018.

\section{METODE}

Penelitian ini merupakan penelitian tindakan kelas kolaboratif antara peneliti dengan guru kelas IV di SD Negeri 1 Wonosari tahun ajaran 2017/2018. Subjek penelitian ini adalah guru dan siswa kelas IV yang berjumlah 21 siswa. Jenis data penelitian ini adalah data kuantitatif berupa penerapan model pembelajaran Group Investigation dengan multimedia dan data kualitatif berupa kerja sama siswa dalam mata pelajaran IPS. Sumber data dalam penelitian ini yaitu guru dan siswa kelas IV. Teknik pengumpulan data menggunakan observasi, wawancara, angket, dan tes. Uji validitas data menggunakan triangulasi teknik dan sumber. Analisis data meliputi reduksi data, penyajian data, dan kesimpulan sesuai model analisis data menurut Miles dan Huberman (Sugiyono, 2012: 246-253).

Indikator kinerja penelitian ini adalah peningkatan kerja sama siswa dalam mata pelajaran IPS dengan ketercapaian target $85 \%$. Penelitian ini memodifikasi prosedur penelitian Kemmis dan Taggart (Arikunto, 2013: 137), yaitu terdiri dari tahap perencanaan, pelaksanaan, pengamatan, dan refleksi.

\section{HASIL DAN PEMBAHASAN}

Penelitian ini dilaksanakan selama tiga siklus dengan menerapkan tujuh langkah model pembelajaran Group Investigation dengan multimedia yaitu: (1) pembentukan kelompok, (2) identifikasi topik dengan multimedia, (3) perencanaan investigasi, (4) pelaksanaan investigasi, (5) membuat laporan akhir, (6) presentasi, dan (7) evaluasi.

Hasil observasi penerapan model pembelajaran Group Investigation dengan multimedia terhadap guru dan siswa mengalami peningkatan pada setiap siklusnya hingga mencapai indikator kinerja penelitian yang ditargetkan yaitu $85 \%$. Hasil observasi kegiatan guru pada siklus I $72,37 \%$, meningkat pada siklus II menjadi $81,15 \%$, dan siklus III mencapai $90,52 \%$, sedangkan kegiatan siswa pada siklus I $70,98 \%$, meningkat pada siklus II menjadi $81,69 \%$, dan siklus III mencapai $88,69 \%$. Berdasarkan hasil observasi dan wawancara, guru berhasil menerapkan langkah langkah model pembelajaran Group Investigation dengan multimedia dan siswa aktif mengikuti pembelajaran dengan baik.

Hasil observasi kerja sama siswa dalam mata pelajaran IPS mengalami peningkatan pada setiap siklus dilihat dari persentase siswa yang memenuhi ketercapaian target, pada siklus I 42,85\%, meningkat pada siklus II menjadi 66,66\%, dan siklus III mencapai $88,09 \%$. Hasil observasi tersebut diperkuat dengan hasil angket. Hasil angket kerja sama siswa dalam mata pelajaran IPS juga mengalami peningkatan pada setiap siklusnya dilihat dari persentase siswa yang memenuhi ketercapaian target, pada siklus I 35,71\%, meningkat pada siklus II menjadi $69,04 \%$, dan siklus III mencapai $88,05 \%$. Selain itu, hasil belajar siswa menunjukkan adanya peningkatan dilihat dari persentase ketuntasan siswa yang memenuhi KKM, pada siklus I $64,28 \%$, meningkat pada siklus II menjadi $76,19 \%$, dan siklus III mencapai $92,85 \%$. 
Dengan demikian penerapan model pembelajaran Group Investigation dengan multimedia dapat meningkatkan kerja sama siswa dalam mata pelajaran IPS dilihat dari persentase siswa yang memenuhi ketercapaian target dari siklus I-III. Hasil penelitian ini memperkuat penelitian yang dilakukan Jajang Nurjaman (2014) dan Wahyuningtiyas (2014) yang menyatakan bahwa penerapan metode Group Investigation dapat meningkatkan kerja sama siswa dilihat perilaku siswa berdasarkan tingkat pencapaian indikator kerja sama yaitu kontribusi setiap anggota kelompok, tanggung jawab kelompok dalam menyelesaikan tugas, penyamaan seluruh pendapat seluruh anggota, dan sikap saling membantu antar anggota kelompok.

\section{SIMPULAN}

Penerapan model pembelajaran Group Investigation dengan multimedia dapat meningkatkan kerja sama siswa dalam mata pelajaran IPS Kelas IV SD Negeri 1 Wonosari tahun ajaran 2017/2018, dibuktikan dengan peningkatan persentase siswa yang memenuhi ketercapaian target kerja sama siswa sebesar $85 \%$.

Berkaitan dengan hasil penelitian yang telah dicapai, peneliti mengajukan saran sebagai berikut: (1) bagi guru, diharapkan dapat mengembangkan model pembelajaran Group Investigation dengan multimedia pada materi atau mata pelajaran lain; (2) bagi sekolah, diharapkan melengkapi sarana dan prasarana pendukung pembelajaran; dan (3) bagi peneliti lain, keberhasilan penelitian ini dapat digunakan sebagai dasar pijakan pengembangan penelitian yang menerapkan model pembelajaran Group Investigation dengan multimedia untuk meningkatkan kerja sama siswa pada mata pelajaran lain.

\section{DAFTAR PUSTAKA}

Apriono, D. (2013). Pembelajaran Kolaboratif: Suatu Landasan untuk Membangun Kebersaman dan Keterampilan Kerjasama. Diklus, 17 (01), 296.

Arikunto, S. (2013). Prosedur Penelitian: Suatu Pendekatan Praktik. Jakarta: Rineka Cipta.

Arsyad, A. (2014). Media Pembelajaran. Depok: Rajagrafindo Persada.

Huda, M. (2015). Cooperative Learning Metode Teknik Struktur dan Model Terapan. Yogyakarta: Pustaka Pelajar.

Isjoni. (2013). Cooperative Learning Efektifitas Pembelajaran Kelompok. Bandung: Alfabeta.

Nurjaman, J. (2014). Penerapan Metode Cooperative Learning Tipe Group Investigation dalam Upaya Menumbuhkan Kerja Sama Siswa dalam Pembelajaran Sejarah. Skripsi Tidak Dipublikasikan. Universitas Pendidikan Indonesia, Bandung.

Permendiknas No. 22 tahun 2006 tentang Standar Isi untuk Pendidikan dasar dan Menengah.

Sugiyono. (2012). Metode Penelitian Pendidikan (Pendekatan Kuantitatif, Kualitatif, dan $R \& D)$. Bandung: Penerbit Alfabeta.

Susanto, A. (2014). Pengembangan Pembelajaran IPS di Sekolah Dasar. Jakarta: Kencana Prenada Media Group. 